\title{
Den omstridte tidstavle - Kvartcer eller ikke Kvartcer
}

Af professor Jan A. Piotrowski, Geologisk Institut, Aarhus Universitet og viceprcesident for INQUA samt intro af Ulla V. Hjuler, GeologiskNyt

Det diskuteres i øjeblikket, hvordan den geologiske tidsskala i grunden skal se ud. Det er primært Kvartær, diskussionen drejer sig om, men afskaffelsen af Tertiær er også oppe til diskussion!

\section{Rod i tavlerne}

På GeologiskNyt lavede vi i 2005 på opfordring vores tavle om, så den nu er baseret på det forslag, som ICS (International Commision on Stratigraphy) har fremsat (se http://www.stratigraphy.org/cheu.pdf). Denne tidstavle er heller ikke korrekt, idet beslutningen om Kvartærets fjernelse fra søjlen ikke er godkendt af IUGS (International Union of Geological Sciences, der overordnet ICS) så derfor har vi nu redigeret den, så den, indtil de endegyldige beslutninger tages, ser ud som søjlen til højre herfor!

ICS' skema er et foreløbigt kompromis, men de gamle præ-Gradstein-termer og grænser er faktisk stadig gyldige (Gradsteintermer: efter Felix Gradsteins store bog med de nuværende tavler). Afskaffelsen af Tertiæret er også oppe til diskussion

Professor Jan A. Piotrowski:

Der er to forslag til ændring af den øverste inddeling af skalaen:

1) INQUA (International Union for Quaternary Research) foreslår en undergrænse for Kvartær på 2,6 mio. år. Endvidere ser de Kvartæret som en periode/et system, der stratigrafisk kommer efter Neogen.

2) ICS foreslår også en undergrænse på 2,6 mio. år, men de ønsker, at Kvartæret benævnes "Subæra", mens Neogen er perioden/systemet, som strækker sig op til nutiden (se udsnit af tidsskalaen i figuren til højre).
Forslag 2 er ikke blevet accepteret af de fleste Kvartær-forskere. IUGS anbefaler, at så længe, endegyldige beslutninger ikke er truffet, skal den "gamle" model fra 1999 gælde. Den siger, at Kvartær er en periode/ et system, som begyndte for 1,8 mio. år siden.

\section{Afgørelse i 2008}

En endegyldig beslutning træffes først i 2008 på International Geological Congress $\mathrm{i}$ Oslo. Indtil da holder vi os hér på Redaktionen til den "gamle" model.

Yderligere information kan fås af forfatteren. Desuden kan man lese mere om debatten i en artikel af Stephen L. Walsh $i$ Earth-Science Reviews, Volume 78, Issues 3-4, October 2006, Pages 207-237 (www.sciencedirect.com)

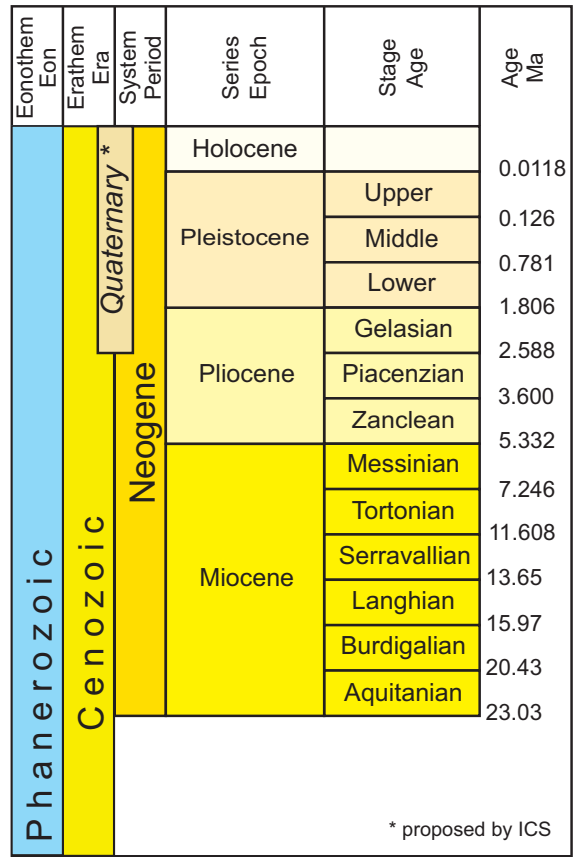

Den øverste del af tidsskalaen som det er foreslået af ICS. (Revideret udsnit efter ICS)

\section{Flere spcendende nyheder?}

Tag et kig på GeologiskNyts hjemmeside: http://www.geologisknyt.dk/

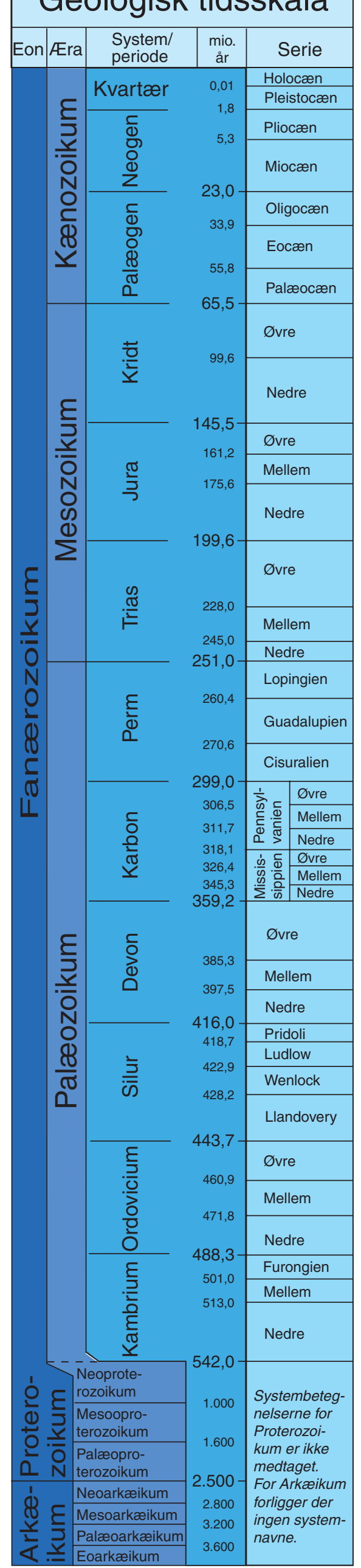

